\title{
ZASTOSOWANIE ZAWIESINY LODOWEJ W KLIMATYZACJI
}

\begin{abstract}
W pracy przedstawiono możliwości zastosowania zawiesiny lodowej w technice klimatyzacyjnej. Zawiesina lodowa jest mieszaniną kryształków lodu i cieczy, którą jest najczęściej woda, lub woda z dodatkiem środka obniżającego jej temperaturę zamarzania. Wytwarzana jest w różnego typu generatorach, z których do najczęściej stosowanych należą mechaniczne generatory skrobakowe. Wykorzystanie zawiesiny lodowej jako nośnika ciepła w systemach klimatyzacyjnych, w stosunku do systemów z wodą lodową wiąże się z wieloma korzyściami, takimi jak: zmniejszenie ilości chłodziwa w układzie, zmniejszenie średnicy rurociągów, zmniejszenie wielkości wymienników ciepła (nawet o 50\%), przy zachowaniu takich samych wydajności. Zastosowanie zawiesiny lodowej w klimatyzacji pozwala na obniżenie temperatury powietrza pierwotnego o $5,5 \mathrm{~K}$, co umożliwia redukcję jego strumienia o ponad $40 \%$. Dodatkowym efektem związanym z niższą temperaturą powietrza pierwotnego są lepsze warunki komfortu, dzięki obniżeniu wilgotności względnej powietrza z 60 do $35 \%$. Te efekty mają wpływ na działanie układu regulacji, gdyż przy takim samym obciążeniu cieplnym obiektu możliwe są wyższe nastawy temperatury o około $1,5 \mathrm{~K}$. Podstawową zaletą instalacji z zawiesiną lodową jest możliwość skojarzenia jej z systemem akumulacji ciepła. Pozwala to na ograniczenie szczytowej mocy urządzenia ziębniczego o $50-80 \%$, redukcję o $80 \%$ napełnienia instalacji czynnikiem ziębniczym oraz wykorzystanie nocnych taryf energii elektrycznej i zmniejszenie kosztów eksploatacyjnych o $25-50 \%$. Stosując zawiesinę lodową można kilkakrotnie zmniejszyć pojemność zbiornika akumulacyjnego.

$\mathrm{W}$ pracy omówiono również przykładowe instalacje klimatyzacyjne z zawiesiną lodową kompleksu budynków i kopalni złota.
\end{abstract}

Słowa kluczowe: nośnik ciepła, generator zawiesiny lodowej, akumulacja ciepła, system klimatyzacyjny

\section{Wstęp}

Zawiesina lodowa (ice slurry) zwana także lodem binarnym, lodem zawiesinowym lub ciekłym lodem jest mieszaniną cieczy bazowej i kryształków lodu o wymiarach do $0,5 \mathrm{~mm}$. Cieczą bazową jest najczęściej woda lub woda

\footnotetext{
${ }^{1}$ Autor do korespondencji/corresponding author: Wojciech Zalewski, Politechnika Krakowska, al. Jana Pawła II 37, 31-864 Kraków, tel. 126283590, e-mail: wzalewski@pk.edu.pl
} 
z dodatkiem środka obniżającego jej temperaturę zamarzania, najczęściej glikolu, alkoholu, rzadziej soli. Na jakość zawiesiny lodowej mają wpływ: rodzaj cieczy, z której jest tworzona, zawartość lodu w mieszaninie (udział masowy) oraz wielkość i kształt kryształków lodu. Wskazane jest, aby kryształki lodu miały globularny kształt i gładkie powierzchnie. Mniejsze jest wtedy ryzyko powstawania czopów, które mogłyby utrudnić przepływ zawiesiny w rurach. Udział masowy lodu w zawiesinie nie przekracza zwykle $40 \%$.

Systemy wykorzystujące zawiesinę lodową w technice chłodniczej i klimatyzacyjnej zaczęły powstawać od początku lat osiemdziesiątych ubiegłego wieku. Obecnie spotyka się je w wielu krajach, między innymi w Japonii, Korei, RPA, Chinach, w krajach Europy Zachodniej. W klimatyzacji czynnik ten jest stosowany głównie $\mathrm{w}$ systemach klimatyzacyjnych dużych obiektów budowlanych (biurowych, handlowych i przemysłowych) oraz kopalń. W Polsce ta technologia chłodzenia nie znalazła jeszcze zastosowania. Spowodowane to jest przede wszystkim wysoką ceną generatorów zawiesiny lodowej i wynikającymi stąd wyższymi, niż w tradycyjnych systemach chłodzenia, kosztami inwestycyjnymi oraz brakiem wiedzy i doświadczenia ze strony inwestorów i projektantów w zakresie projektowania i eksploatacji instalacji z zawiesiną lodową.

Zawiesiny lodowe wytwarzane są za pomocą tzw. generatorów zawiesiny lodowej, różniących się zasadą działania i budową. Najczęściej stosowanymi tego typu urządzeniami są mechaniczne generatory skrobakowe. Wytwarzanie lodu ma miejsce w parowaczu generatora, w którym lód zeskrobywany jest z powierzchni chłodzonej przez obracające się ostrza, noże, pręty lub szczotki. $\mathrm{Na}$ rysunku 1 przedstawiono schemat skrobakowego generatora zawiesiny lodowej z parowaczem z ostrzami zeskrobującymi lód, osadzonymi na obracającym się wale.
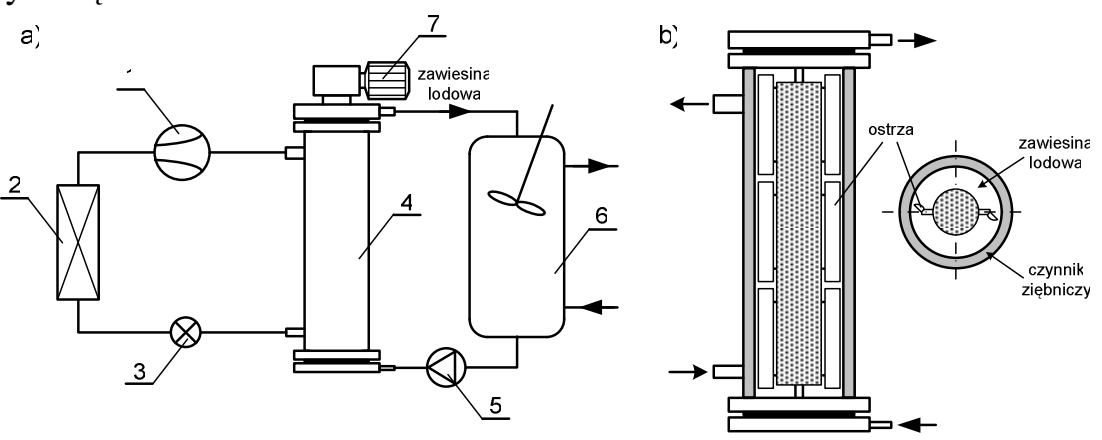

Rys. 1. Generator skrobakowy zawiesiny lodowej ze zbiornikiem akumulacyjnym, na podstawie [8]; a) schemat instalacji: 1 - sprężarka, 2 - skraplacz, 3 - zawór, 4 - parowacz, 5 - pompa, 6 - zbiornik akumulacyjny, 7 - silnik; b) parowacz

Fig. 1. Scraped ice slurry generator with the storage tank, based on [8]; a) schematic diagram of the plant: 1 - compressor, 2 - condenser, 3 - valve, 4 - evaporator, 5 - pump, 6 - storage tank, 7 - motor; b) evaporator 


\section{Charakterystyka zawiesiny lodowej jako chłodziwa}

Przewaga zawiesiny lodowej nad tradycyjnymi chłodziwami wynika z dużej właściwej wydajności cieplnej, dużego współczynnika przewodzenia ciepła, neutralności wobec środowiska oraz możliwości wykorzystania zawiesiny lodowej nie tylko jako nośnika ciepła, ale także jako medium akumulującego ciepło. Wadami zawiesiny lodowej w stosunku do innych chłodziw są: większa lepkość, skłonność do zbrylania się oraz zmienność w czasie właściwości reologicznych, spowodowana efektem „starzenia się" kryształków lodu.

Podstawową zaletą instalacji z zawiesiną lodową jest możliwość skojarzenia jej z systemem akumulacji ciepła. Pozwala to na ograniczenie szczytowej mocy urządzenia ziębniczego o 50 - 80\%, redukcję o 80\% napełnienia instalacji czynnikiem ziębniczym oraz wykorzystanie taryf nocnych energii elektrycznej i zmniejszenie kosztów eksploatacyjnych o 25-50\% [1]. Stosując zawiesinę lodową można kilkakrotnie ( 2 do 10 razy) zmniejszyć pojemność zbiornika akumulacyjnego. Porównanie wartości stosunku zmiany wartości właściwej wydajności cieplnej wodnej zawiesiny lodowej $\Delta \mathrm{i}_{\mathrm{zl}} \mathrm{O}$ różnym udziale masowym lodu $\mathrm{X}_{\mathrm{s}}$ do zmiany entalpii właściwej wody $\Delta \mathrm{i}_{\mathrm{w}}$ przy zmianie temperatury obu chłodziw o $6 \mathrm{~K}$ przedstawia wykres na rysunku 2.

Rys. 2. Porównanie właściwej wydajności cieplnej zawiesiny lodowej i wody $(\Delta \mathrm{T}=6 \mathrm{~K})$

Fig. 2. Cooling capacity comparison between ice slurry and water $(\Delta \mathrm{T}=6 \mathrm{~K})$

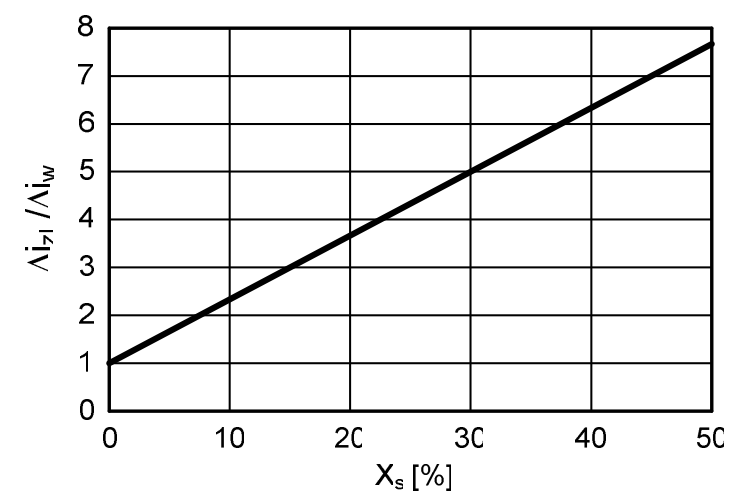

Większa właściwa wydajność cieplna zawiesiny lodowej w stosunku do tradycyjnych czynników pośredniczących umożliwia zmniejszenie strumienia masy zawiesiny i redukcję nawet o 50\% średnic rur i prędkości przepływu. Wpływa to na obniżenie kosztów instalacji oraz ograniczenie średnio do 12,5\% zużycia energii związanej z transportem chłodziwa [3].

Tabela 1 zawiera porównanie średnic wewnętrznych rur dla przepływu wody ( $0 \%$ zawartości lodu) i wodnej zawiesiny lodowej, zapewniających transport strumienia ciepła 10 lub $250 \mathrm{~kW}$ przy stałej temperaturze zawiesiny $(\Delta \mathrm{T}=0)$ oraz przy zmianie temperatury chłodziw o 6 i $12 \mathrm{~K}$. Wartości średnic rur odpowiadają prędkości przepływu czynników równej $1 \mathrm{~m} / \mathrm{s}$. 
Tabela 1. Porównanie średnicy rur dla wody i wodnej zawiesiny lodowej (dla prędkości przepływu $1 \mathrm{~m} / \mathrm{s}$ )

Table 1. Pipes diameter comparison for water and water ice slurry (for flow velocity $1 \mathrm{~m} / \mathrm{s}$ )

\begin{tabular}{|c|c|c|c|c|c|c|}
\hline \multirow{3}{*}{$\begin{array}{c}\text { Strumień ciepła } \\
{[\mathrm{kW}]}\end{array}$} & \multirow{3}{*}{$\begin{array}{c}\text { Zmiana } \\
\text { temp. } \\
\Delta \mathrm{T},[\mathrm{K}]\end{array}$} & \multicolumn{5}{|c|}{ Zawartość lodu, [\%] } \\
\hline & & $\mathbf{0}$ & 10 & 20 & 30 & 40 \\
\hline & & \multicolumn{5}{|c|}{ Średnica rury, [mm] } \\
\hline \multirow{3}{*}{10} & 0 & - & 20 & 14 & 11 & 10 \\
\hline & 6 & 22 & 15 & 12 & 10 & 9 \\
\hline & 12 & 16 & 12 & 10 & 9 & 8 \\
\hline \multirow{3}{*}{250} & 0 & - & 98 & 69 & 56 & 49 \\
\hline & 6 & 112 & 74 & 59 & 50 & 45 \\
\hline & 12 & 79 & 62 & 52 & 46 & 42 \\
\hline
\end{tabular}

W odróżnieniu od chłodziw konwencjonalnych, praktycznie stała temperatura zawiesiny lodowej pozwala na uzyskanie większej różnicy temperatur czynników w wymiennikach ciepła, przez co możliwe jest stosowanie wymienników o mniejszych powierzchniach wymiany ciepła. Dzięki prawie stałej temperaturze topnienia lodu osiągane są większe sprawności wymienników ciepła i można uzyskać niższą temperaturę medium chłodzonego. Zastosowanie zawiesiny lodowej $\mathrm{w}$ klimatyzacji pozwala na obniżenie temperatury powietrza pierwotnego nawet o 5,5 K, co umożliwia redukcję jego strumienia o ponad $40 \%$. Mniejsze przekroje kanałów wentylacyjnych zmniejszają koszty wykonania instalacji powietrza. Dodatkowym efektem związanym z niższą temperaturą powietrza pierwotnego (np. $7,5^{\circ} \mathrm{C}$ zamiast $13^{\circ} \mathrm{C}$ ) są lepsze warunki komfortu, dzięki obniżeniu wilgotności względnej powietrza z 60 do 35\%. Te efekty mają wpływ na działanie układu regulacji, gdyż przy takim samym obciążeniu cieplnym obiektu możliwe są wyższe nastawy temperatury o około 1,5 K [10].

Wykres na rysunku 3 obrazuje wpływ rodzaju chłodziwa na wydajność cieplną chłodnicy powietrza. Przedstawia on wyniki badań doświadczalnych wydajności cieplnej ożebrowanej chłodnicy powietrza zasilanej wodnym roztworem

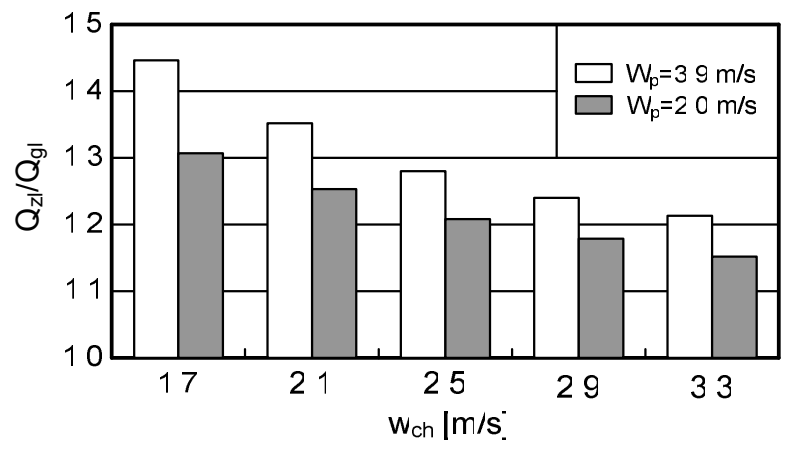

Rys. 3. Wartości stosunku wydajności ciepl-nych chłodnicy powietrza $\left(\mathrm{Q}_{\mathrm{zl}} / \mathrm{Q}_{\mathrm{gl}}\right)$ w funkcji prędkości przepływu chłodziwa, na podstawie [5]

Fig. 3. The values of cooling capacity ratio $\left(\mathrm{Q}_{\mathrm{z}} / \mathrm{Q}_{\mathrm{gl}}\right)$ as a function of coolant flow velocity in the air cooler, based on [5] 
glikolu etylenowego $\left(\mathrm{Q}_{\mathrm{gl}}\right)$ i zawiesiną lodową utworzoną na bazie roztworu alkoholu etylowego $\left(\mathrm{Q}_{\mathrm{zl}}\right) \mathrm{w}$ funkcji prędkości przepływu chłodziwa $\mathrm{w}_{\mathrm{ch}}$, dla różnych prędkości przepływu powietrza $\mathrm{w}_{\mathrm{p}}$ przez wymiennik. $\mathrm{Z}$ wykresu wynika, że wydajność wymiennika zasilanego zawiesiną lodową jest większa o 15 do $44 \%$, w zależności od prędkości przepływu chłodziwa i powietrza [5]. Wzrost wydajności cieplnej chodnicy zasilanej zawiesiną $\mathrm{w}$ stosunku do chłodnicy zasilanej roztworem wodnym glikolu jest większy dla wyższych prędkości przepływu powietrza $\left(\mathrm{w}_{\mathrm{p}}=3,9 \mathrm{~m} / \mathrm{s}\right)$, ponieważ wtedy większy jest wpływ współczynnika przejmowania ciepła po stronie chłodziwa na wartość współczynnika przenikania ciepła chłodnicy.

Cechą eksploatacyjną instalacji z zawiesiną lodową jest prosta regulacja polegająca na włączaniu i wyłączaniu pompy współpracującej z wymiennikiem ciepła. Pewnym niebezpieczeństwem w stosowaniu tego chłodziwa jest możliwość zatykania się instalacji i nierównomiernego rozdziału czynnika (należy unikać trójników i rozdzielaczy). Instalacje z zawiesiną lodową są wyposażane w dodatkowe pompy czynnika pomiędzy generatorem lodu i zbiornikiem akumulacyjnym. Także konieczność eliminacji segregacji lodu w zbiorniku akumulacyjnym za pomocą mieszadeł o mocy $25-70 \mathrm{~W} / \mathrm{m}^{3}$ zwiększa zużycie energii elektrycznej. Jednak dzięki obniżeniu szczytowej mocy urządzenia i zmniejszeniu mocy napędowej pomp obiegowych i wentylatorów uzyskuje się istotnie niższe koszty eksploatacyjne instalacji z zawiesiną lodową. Ważnym ograniczeniem w stosowaniu tego chłodziwa jest wysoka cena generatorów zawiesiny. Typowy czas amortyzacji instalacji z zawiesiną lodową wynosi od 2 - 4,5 lat [1]. Dla dużych instalacji o mocy powyżej $1 \mathrm{MW}$ czas amortyzacji jest krótszy i wynosi około jeden rok.

\section{Systemy klimatyzacyjne $z$ zawiesiną lodową}

Systemy klimatyzacyjne z zawiesiną lodową łączą zazwyczaj ze sobą dwie funkcje: produkcję zawiesiny lodowej i jej wykorzystanie do magazynowania energii (chłodu). System produkcji zawiesiny uruchamiany jest w okresie, gdy tańsza jest energia elektryczna (głównie w nocy), a w ten sposób zmagazynowany chłód wykorzystywany jest w okresie największego na niego zapotrzebowania (w dzień). Przykładowo, w systemie klimatyzacji obiektu o maksymalnym obciążeniu cieplnym wynoszacym $300 \mathrm{~kW}$, dzięki akumulacji zimna możliwe jest zainstalowanie układu o mocy $75 \mathrm{~kW}$, przy pojemności zasobnika zawiesiny lodowej $25 \mathrm{~m}^{3}$.

Typowy system klimatyzacji składa się z trzech obiegów: obiegu czynnika ziębniczego ( $w$ generatorze), zawiesiny lodowej i wody lodowej. Zawiesina lodowa może pełnić funkcję czynnika pośredniczącego, krążącego między wymiennikiem wody lodowej i zbiornikiem akumulacyjnym. Woda lodowa chłodzona jest zawiesiną lodową $\mathrm{w}$ wymienniku wody lodowej i dostarczana następnie do układu klimatyzacji. Możliwe jest także bezpośrednie zasilanie ukła- 


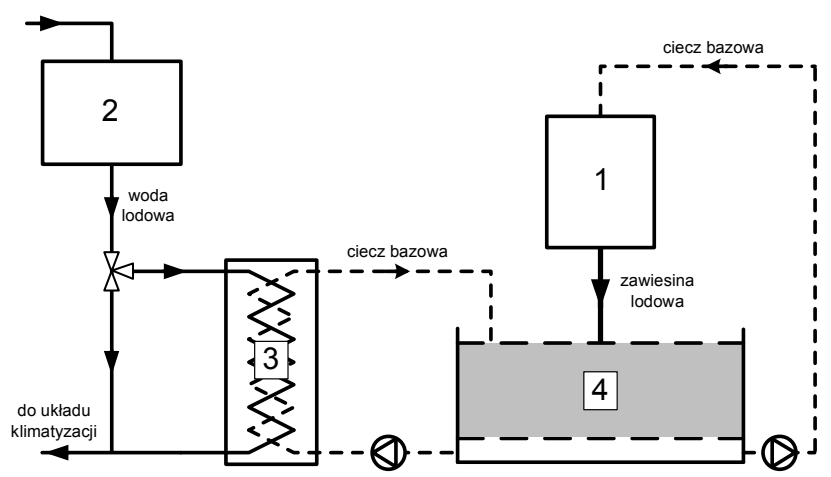

Rys. 4. Skojarzony układ chłodzenia wytwornicy wody lodowej i generatora zawiesiny lodowej, na podstawie [7]: 1 - generator zawiesiny lodowej, 2 - wytwornica wody lodowej, 3 - wymiennik ciepła, 4 - zbiornik zawiesiny lodowej

Fig. 4. A combined cooling system of an ice water generator and an ice slurry generator, based on [7]: 1 - ice slurry generator, 2 - ice-cold water generator, 3 - heat exchanger, 4 - ice slurry tank

du klimatyzacji zawiesiną lodową. Stosuje się również skojarzone układy wytwornicy wody lodowej i generatora zawiesiny lodowej jak na rysunku 4. $\mathrm{W}$ okresach mniejszego zapotrzebowania na zimno (np. w nocy) woda lodowa kierowana jest bezpośrednio do systemu klimatyzacji (z pominięciem wymiennika ciepła (3)), a generator (1) wytwarza w tym czasie zawiesinę lodową. W okresie dużego obciążenia cieplnego systemu woda lodowa schładzana jest dodatkowo w płytowym wymienniku ciepła (3), włączonym w obieg generatora zawiesiny lodowej. Układy skojarzone charakteryzują się niższymi kosztami eksploatacyjnymi w stosunku do innych rozwiązań z zawiesiną lodową [7]. W systemach klimatyzacyjnych zaleca się stosowanie zawiesiny lodowej o temperaturze $-2^{\circ} \mathrm{C}$.

Przykładem systemu klimatyzacji z akumulacją zimna w zawiesinie lodowej, stosowanego w klimatyzacji budynków jest system, którego schemat ideowy przedstawiono na rysunku 5. Nosi on nazwę CLIS-HR (Crystal Liquid Ice System whith Heat Recovery) [9]. Instalacja jest w stanie pokryć zapotrzebowanie na chłód budynku, a dzięki odzyskowi ciepła z generatora zawiesiny lodowej, pokrywa także zapotrzebowanie na ciepło. System CLIS-HR zastosowano w komleksie budynków Ritz Carlton Plaza w Osace (Japonia) o powierzchni użytkowej około 137 tyś $\mathrm{m}^{2}$ i wysokości $181 \mathrm{~m}$. Instalacja składa się z 31 skrobakowych generatorów zawiesiny lodowej o wydajności chłodniczej 260 kW każdy i z 16 zasobników zawiesiny lodowej mogących zakumulować łącznie około 81 tyś. kWh energii. Zastosowanie zawiesiny lodowej doprowadziło do obniżenia zużycia energii napędowej pomp i urządzeń w stosunku do konwencjonalnego systemu klimatyzacji o ponad $30 \%\left(\mathrm{z} 12,5 \mathrm{~W} / \mathrm{m}^{2}\right.$ do $\left.8 \mathrm{~W} / \mathrm{m}^{2}\right)[9]$. 


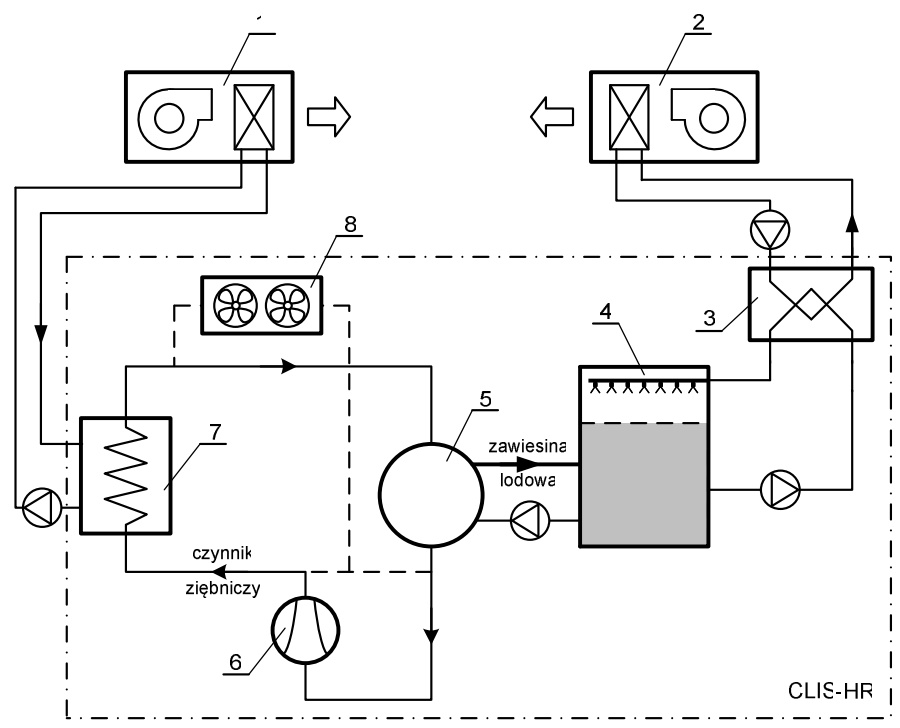

Rys. 5. Schemat systemu klimatyzacji CLIS-HR, na podstawie [9]: 1 - klimatyzator (ogrzewa-nie), 2 - klimatyzator (chłodzenie), 3 - wymiennik ciepła, 4 - zasobnik zawiesiny lodowej, 5 - parowacz, 6 - sprężarka, 7 - skraplacz, 8 - powietrzny wymiennik ciepła

Fig. 5. Schematic diagram of the CLIS-HR air conditioning system, based on [9]: 1 - air conditioner (heating), 2 - air conditioner (cooling), 3 - heat exchanger, 4 - ice slurry storage tank, 5 - evaporator, 6 - compressor, 7 - condenser, 8 - air heat exchanger

Wykorzystanie zawiesiny lodowej $\mathrm{w}$ systemach klimatyzacyjnych nie ogranicza się tylko do klimatyzacji obiektów budowlanych. Sektorem wykorzystującym tę technologię jest także górnictwo, gdzie zawiesina lodowa jest stosowana w systemach chłodzenia powietrza w kopalniach. Ze względu na coraz większe głębokości kopalni oraz coraz większe długości rurociągów stosowanie tradycyjnych rozwiazań wykorzystujących wodę lodową stało się nieopłacalne. Dzięki temu, że zawiesina lodowa charakteryzuje się większą właściwą wydajnością cieplną, możliwe jest zmniejszenie strumienia przepływającego chłodziwa, a tym samym obniżenie kosztów jego transportu. Istotnym problemem zwiazanym ze stosowaniem wody lodowej jest wzrost temperatury wody wraz z głebokością, spowodowany przyrostem energii potencjalnej. Na rurociągu o długości $1000 \mathrm{~m}$ temperatura wody lodowej może wzrosnąć o ponad 2,3 K [1]. Przyrost temperatury chłodziwa wiąże się z koniecznościa stosowanie większych chłodnic powietrza. W przypadku zastosowania zawiesiny lodowej przyrost energii potencjalnej powoduje topnienie kryształków lodu, przy tylko nieznacznie zmieniającej się temperaturze.

Wytwarzana na powierzchni zawiesina jest zazwyczaj dostarczana do wymienników ciepła znajdujących się pod ziemią. Tego typu systemy są z powodzeniem eksploatowane w Republice Południowej Afryki i w Chinach. W RPA zawiesinę lodową wykorzystuje się głównie w kopalniach o dużych 
głębokościach (powyżej $3000 \mathrm{~m}$ ). Takie instalacje znajdują się między innymi w kopalniach złota Mponeng koncernu Anglo Gold Ashanti. Dwanaście wytwornic zawiesiny lodowej zapewnia łącznie $36 \mathrm{MW}$ mocy chłodniczej dla wyrobisk położonych na głębokości około $4000 \mathrm{~m}$. Do produkcji zawiesin lodowych wykorzystuje się próżniowe generatory zawiesin lodowych. Wytwarzają one zawiesinę lodową o $70-80 \%$ zawartości lodu w ilości 5600 ton lodu na dobę. Zastosowanie zawiesiny lodowej w kopalni złota Mponeng pozwoliło na obniżenie temperatury powietrza $\mathrm{w}$ wyrobiskach do poziomu poniżej $27,5^{\circ} \mathrm{C}$ z pierwotnego poziomu $54,5^{\circ} \mathrm{C}$. W Chinach zaczęto stosować zawiesinę lodową w kopalniach o mniejszych głębokościach, poniżej $1000 \mathrm{~m}$.

Na rysunku 6 przedstawiono schemat systemu dystrybucji zawiesiny lodowej w kopalni złota [2]. Do schładzania powietrza stosuje się wytworzoną na powierzchni zawiesinę lodową o 75\% zawartości lodu, która transportowana jest przenośnikiem taśmowym i pionową rurą o dużej średnicy pod ziemię. Na skutek zysków ciepła zawartość lodu w zawiesinie maleje i w podziemnych zasobnikach lodu (2) wynosi około 67,5\%. Po wykorzystaniu jej w odbiornikach zimna (3), powstała z zawiesiny woda magazynowana jest w podziemnych zbiornikach wody powrotnej (4) i kierowana na powierzchnię. Temperatura wody w zbiorniku (5) na powierzchni wynosi około $20^{\circ} \mathrm{C}$ [6]. Po wstępnym jej schłodzeniu do temperatury $3-6^{\circ} \mathrm{C}$ w chłodni kominowej (6), i w razie potrzeby w dodatkowej chłodnicy (7), powraca ona do próżniowych generatorów zawiesiny lodowej.

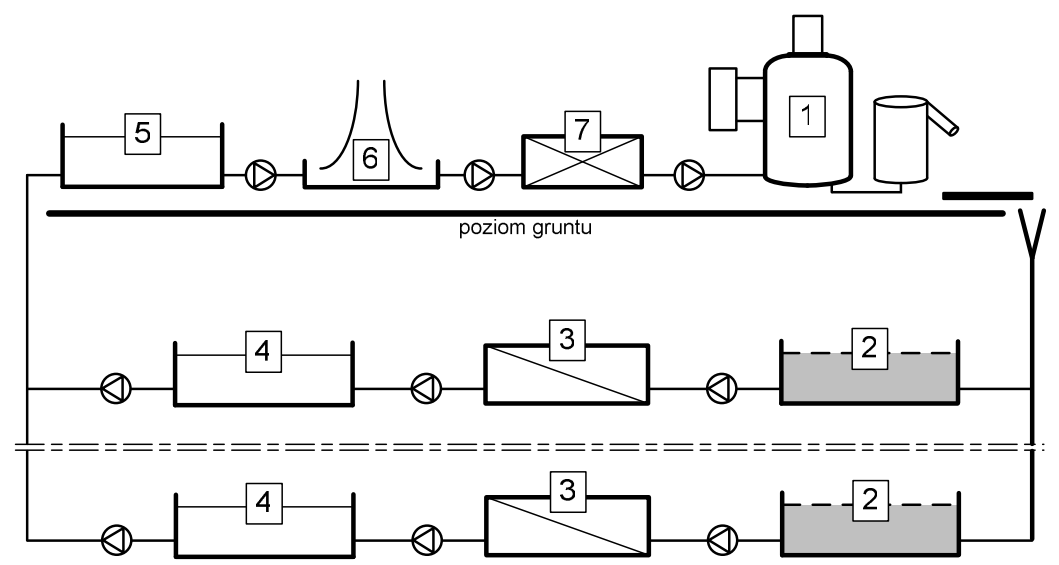

Rys. 6. Schemat systemu dystrybucji zawiesiny lodowej w kopalni złota, na podstawie [2]: 1 - próżniowy generator zawiesiny lodowej, 2 - zasobnik zawiesiny lodowej, 3 - odbiornik zimna, 4 - zbiornik wody powrotnej, 5 - zbiornik wody gorącej, 6 chłodnia kominowa, 7 - chłodnica wody

Fig. 6. Schematic diagram of the ice slurry distribution system in a gold mine, based on [2]: 1 - vacuum ice maker, 2 - ice slurry dam, 3 - load, 4 - return water dam, 5 hot water tank, 6 - cooling tower, 7 - water chiller 
Z analizy przeprowadzonej w pracy [2] wynika, że zastosowanie instalacji z zawiesiną lodową może być zasadne również w kopalniach o mniejszych głębokościach. Porównanie wartości współczynnika wydajności systemu $\varepsilon$ z zawiesiną lodową (1) i wodą lodową (2) dla różnych głębokości kopalni H przedstawiono na rysunku 7. Wartości tych współczynników wyrównują się już przy głębokości około $\mathrm{H}=900 \mathrm{~m}$. Dla większych głębokości efektywność systemu $\mathrm{z}$ zawiesiną lodową jest wyższa od efektywności instalacji z wodą lodową.

Rys. 7. Porównanie wartości współczynnika wydajności $\varepsilon$ systemu z zawiesiną lodową (1) i wodą lodową (2), na podstawie [2]

Fig. 7. Coefficient of performance comparison for a system with ice slurry (1) and ice-cold water (2), based on [2]

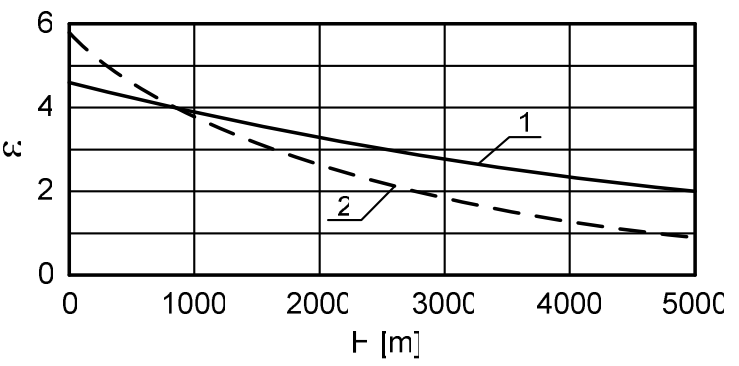

\section{Wnioski}

Zawiesina lodowa może być stosowana w systemach klimatyzacyjnych jako zamiennik wody lodowej lub w systemach skojarzonych - razem z wodą lodową. Podstawową zaletą zawiesin lodowych jest duża właściwa wydajność cieplna oraz możliwość wykorzystania ich zarówno do transportu, jak i do akumulacji zimna. Głównym ograniczeniem w stosowaniu zawiesin w układach klimatyzacji jest stosunkowo wysoka cena generatorów. $Z$ drugiej strony, zastosowanie rur o mniejszych średnicach, mniejszych wymienników ciepła i zbiorników akumulacyjnych wpływa na obniżenie kosztów inwestycyjnych instalacji. Możliwe jest także znaczne obniżenie, w stosunku do tradycyjnych systemów klimatyzacyjnych, kosztów eksploatacyjnych, szczególnie w przypadkach, gdy istnieje możliwość okresowego wykorzystywania energii elektrycznej o obniżonej cenie.

Przedstawione w artykule informacje dotyczące techniczno-ekonomicznych aspektów stosowania zawiesin lodowych w klimatyzacji oparte są na doświadczeniach innych, niż Polska, krajów. Jednoznaczna ocena celowości wykorzystania zawiesiny lodowej w polskich warunkach wymaga przeprowadzenia szczegótowej analizy, uwzględniającej nasze krajowe realia.

\section{Literatura}

[1] Bellas I., Tassou S.: Present and future applications of ice slurries, International Journal of Refrigeration, no. 28, 2005, pp. 115-121.

[2] Efrat T., Rott S.: 27MW industrial cooling applications based on the ide's energy efficient vacuum icemaker, 9th IIR Conference on Phase-Change Materials and Slurries for Refrigeration and Air Conditioning, Sofia, 2010. 
[3] Egolf P.W., Kauffeld M.: From physical properties of ice slurries to industrial ice slurry applications, International Journal of Refrigeration, no. 28, 2005, pp. 4-12.

[4] Kauffeld M., Wang M.J., Goldstein V., Kasza K.E.: Ice slurry applications, International Journal of Refrigeration, no. 33, 2010, pp. 1491-1505.

[5] Mika Ł., Zalewski W.: Ocena możliwości zastosowania lodu zawiesinowego do zasilania oziębiaczy powietrza, Inżynieria i Aparatura Chemiczna, nr 3, 2004, s. 112-113.

[6] Mika Ł.: Zastosowanie zawiesiny lodowej jako chłodziwa w układach chłodzenia powietrza w kopalni, Szkoła Eksploatacji Podziemnej, Materiały Konferencyjne, Kraków 2014.

[7] Niezgoda-Żelasko B., Zalewski W.: Techniczne i ekonomiczne aspekty stosowania zawiesiny lodowej w systemach chłodniczych i klimatyzacyjnych, Design and Operation of Environmentally Friendly Refrigeration and AC Systems, Mat. Międzynarodowej Konferencji Chłodniczej, Poznań 2008, s. 151-158.

[8] Zalewski W.: Systemy i urządzenia chłodnicze, Wydawnictwo Politechniki Krakowskiej, Kraków 2012.

[9] Sunwell. Thermal storage. Installation example, http://www.sunwell.com/thermalstorage.html [dostęp: 31 marca 2014 r.].

[10] Thermal energy storage for space cooling, US Department of Energy. http://www.eren.doe.gov/femp [dostęp: 31 marca 2014 r.].

\section{APPLICATION OF ICE SLURRY FOR AIR CONDITIONING}

\section{S u m m a r y}

The paper presents the possibility of using ice slurry in air conditioning. Ice slurry is a mixture of ice crystals and liquid, which is mostly water, or water with the addition of a freezing point lowering agent. It is produced in different types of generators, mostly in mechanical scraped generators. The benefits of using ice slurry as a coolant in air conditioning systems, when compared to systems fed witch ice-cold water, include reducing the amount of coolant in the system, reducing the diameter of the piping, reducing the size of the heat exchangers by up to $50 \%$, while maintaining the same cooling capacity. The use of ice slurry in air conditioning makes it possible to lower primary air temperature by $5,5 \mathrm{~K}$, which enables a reduction of its flux by more than $40 \%$. An additional effect connected with the lower temperature of primary air is the improvement of comfort conditions, which results from reducing the relative humidity of air from 60 to $35 \%$. These effects have an influence on the operation of the regulation system, since, with the same thermal load of a building, it is possible to set higher temperature by circa $1,5 \mathrm{~K}$. The main advantage of ice slurry based installations is the ability to combine them with a thermal storage system. This makes it possible to reduce the peak power of the refrigeration appliance by 50 $80 \%$, as well as to reduce the refrigerant level in the installation by $80 \%$, use night electricity tariffs and reduce operating costs by $25-50 \%$. Using ice slurry also makes it possible to reduce storage tank capacity several times.

The paper also looks at air conditioning systems with ice slurry in a building complex and a gold mine.

Keywords: coolant, ice slurry generator, thermal storage, air conditioning system

Przestano do redakcji: 07.04.2015 r.

Przyjęto do druku: 22.06.2015 r.

DOI:10.7862/rb.2015.86 